\title{
A Colocação das Palavras
}

\section{Antônio de Abreu Rocha}

«Nas manhãs da passada Primavera

Com que delícia etérea nos amamos!

Iremos ver os nomes que traçamos

No rude tronco em que se enlaça a hera.»

(Gonçalves Crespo)

No "latim vulgar" há tendência para a ordem direta. As "línguas românicas" - Sousa da Silveira, Lições de Português, 341, ss - seguem o mesmo caminho. O Português usa, de modo geral indistintamente, a ordem natural e a inversa. O emprego mais freqüente da ordem indireta nota-se principalmente na poesia. Mas, mesmo na prosa, as normas fixas são inviáveis.

Se fosse possivel, a "ordem direta" seria assim:

"Eu estava em pedaços, mas não sentia dor nenhuma."

(Monteiro Lobato)

a) sujeito (eu) ;

b) predicado (estava em pedaços; não sentia dor nenhuma);

c) depois do verbo: predicativo (em pedaços) ou complementos (dor nenhuma);

d) "e entrouxar o cano na boca da onça" (Monteiro Lobato) : o adjunto adverbial depois dos complementos "na boca da onça" (adjunto adverbial); depois de "o cano" (objeto direto) . 
Ocorrem habitualmente as seguintes colocações:

a) "Senhor João, gritei eu, esconda-se aí."

Posposição do sujeito nas orações intercaladas;

b) "Velha és tu, minha Amiga!"

"Belo é o sonho de criança!"

Posposição do sujeito, se o predicativo é um qualificativo;

c) "Como vai você?"

"Quando virá o ajudante?"

"Onde está o caderno?"

Posposição do sujeito, nas interrogações diretas, com advérbios interrogativos;

d) "Chegando o Padre à igreja, percebeu a mudança dos bancos." "Será melhor comparecendo todos."

Posposição do sujeito, nas orações gerundivas adverbiais;

e) "Passada esta tão próspera vitória,

"Tornando Afonso à lusitana terra," (Camões)

Posposição do sujeito, nas orações reduzidas de particípio passado, correspondentes ao "ablativo absoluto" latino;

f) "Vimos chegar as crianças." "Deixou entrar todo mundo":

$\mathrm{Na}$ "língua literária", posposição do sujeito, nas construções do "acusativo com infinitivo", se o sujeito é um "nome" e não um "pronome";

g) "Compram-se jornais e revistas." "Salvou-se o livro." Posposição do sujeito, para dar relevo ao processo verbal, nas construções da voz passiva sintética;

h) "Quisera ela ter-me a seu lado!" "Valha-me Deus!" Posposição do sujeito, nalgumas frases optativas;

i) "Filho meu não trabalha." "Pai nosso que estais no céu." Posposição do possessivo, com efeito especial.

\section{Adjetivo:}

A colocação do adjetivo, em relação ao substantivo modificado, é geralmente indiferente, salvo casos especiais.

Alguns adjetivos mudam de significação, conforme a posição em relação ao substantivo: 
um bom livro $=$ agradável $;$ um livro bom $=$ de qualidade;

homem bom $=$ bondoso; bom homem $=$ honesto;

caro rapaz $=$ estimado; rapaz caro $=$ dispendioso;

menino pobre $=$ sem recurso; pobre menino $=$ infeliz;

gentil-homem = fidalgo; homem gentil = delicado;

assunto verdadeiro $=$ verídico; verdadeiro assunto $=$ real;

homem rico $=$ de fortuna; rico homem $=$ feliz;

livro grande $=$ quanto ao tamanho; grande livro = ótimo;

falso amor $=$ que não existe; amor falso $=$ infiel ;

mão-única $=$ só vai para um lado; única mão = não há outra; anedota simples $=$ sem complicação; simples anedota $=$ apenas anedota;

um livro novo $=$ recente; $u$ m novo livro $=$ mais $u$..

Os antigos adjetivos "explicativos" (exprimem qualidade inerente ao ser) geralmente ficam antes do substantivo: o frio gelo; o claro sol; a branca neve; o duro ferro.

Também os qualificativos de nomes próprios: o imortal Camões, o suave Petrarca, a legendária Atenas.

São geralmente pospostos:

a) os gentílicos: povo inglês, literatura francesa;

b) os referenciais: doutrina cristã, eloqüência ciceroniana, filosofia aristotélica, gênero teatral, coragem varonil, direito civil, disposição férrea, entusiasmo patriótico;

c) os "que denotam uma espécie, uma designação ou classificação científica, técnica ou discriminativa" (Cláudio Brandão): "eletricidade negativa, agulha magnética, escala diatônica, geometria descritiva, artilharia pesada, arma defensiva, batalha naval", gramática normativa, curso ginasial, escola normal, assembléia legislativa, curso comercial, redação oficial, material didático, curso técnico, colégio universitário, curso superior, garrafa térmica, água gelada, cadeira giratória, samba rasgado;

d) os que exprimem forma: figura triangular, rosto oval, linha curva, mesa redonda, linha espiral; 
e) os que exprimem gosto: sabor acre, leite azedo, água doce, vinho amargo, carne salgada;

f) quando o adjetivo precisa de complemento (nominal): terreno próprio para construção, instituição útil à sociedade, medida necessária à ordem pública;

g) os adjetivos verbais: homem comilão, água fervente, nação civilizada, horizonte perdido;

Há locuções formadas de adjetivos e substantivos que têm colocação fixa (Cláudio Brandão, 674) : "pública-forma, pátrio-poder, rico-homem, livre pensamento, franco atirador, água viva, água doce, ama-seca, caixa-forte, em voz baixa, à falsa fé, à tripa forra, à pura ou à fina forca, a pé quedo, de boa mão, livre arbítrio, alto e baixo relevo, extrema-unção, ponto falso, câmara lenta", de segunda mão, de peito aberto, cara-dura, a meio pau, a bandeiras despregadas, a duras penas.

Há colocação fixa nalgumas composições só de adjetivos: azul-claro, verde-escuro, cinza-claro, azul-celeste, azul-marinho, preto-retinto, verde-garrafa, verde-oliva, amarelo-ouro, rosa-choque, verde-abacate.

"Mero e meio antecedem o substantivo, exceto em parede-meia: mero sofisma, mera utopia, meio-dia, meia-noite, meio pão, meialua", meio bobo, meio triste.

Ficam geralmente pospostos adjetivos que indicam cor: lápis marron, blusa alaranjada, carro preto, camisa grená, paletó cinza, campina verde, face vermelha, canário amarelo, capim branco, céu azul. Variação: sagrada face.

Outras palavras têm significação de acordo com a posição: emprego certo $=$ bem escolhido; certo emprego = determinado; adjetivo pronome indefinido

o mesmo homem de ontem = conhecido;

o mesmo homem (ou o homem mesmo) se salvará = próprio;

o homem se salvará mesmo = de fato, realmente (adv.); diversas vezes $=$ certo número de vezes; vezes diversas $=$ diferentes; 
diferentes cores $=$ variadas $;$ cores diferentes $=$ desiguais

vários assuntos $=$ certo número de; assuntos vários $=$ diferentes;

outros assuntos = novos; assuntos outros = diversificados;

muitos livros = vários; livros muitos = outros;

algum amigo $=$ qualquer; amigo algum $=$ nenhum .

Os pronomes possessivos são geralmente antepostos. Mas há casos especiais:

meu amigo (normal); amigo meu (ênfase);

minhas saudades $=$ que eu tenho; saudades minhas $=$ que outrem tem de mim;

espero suas notícias = informações de alguém para mim;

espero notícias suas = informações sobre alguém;

meu trabalho $=$ que me pertence; trabalho meu = que eu fiz;

despedidas minhas $=$ quando despediram de mim;

minhas despedidas $=$ quando eu me despeço de outrem.

\section{Artigo:}

"O Pássaro e a Flor

Era num dia sombrio

Quando um pássaro erradio

Veio parar num jardim.

Aí fitando uma rosa,

Sua voz triste e saudosa,

Pôs-se a improvisar assim." (Castro Alves)

$O$ artigo tem posição fixa, antes do substantivo que modifica.

\section{Observação:}

"O das águas gigante caudaloso" (G. Magalhães)

Podem dar-se inversões depois do artigo, mas este estará sempre antes do substantivo. 
Preposição:

"Levei-a para casa, curei-a e tive-a lá por uns meses num cercado. Por fim soltei-a. Não vai comigo isso de escravizar os pobres animaizinhos que Deus fez para vida solta."

(Monteiro Lobato, Negrinha, 150)

A preposição ocupa lugar fixo, antes da palavra que rege.

\section{Numeral:}

1) "Um homem prevenido vale por dois" (homens).

O numeral cardinal ocupa lugar fixo, antes do substantivo: "um lapis, dois livros, três cadernos".

a) "No dia 4 do mês seguinte" (M. Lobato, ib., 168). "Negrinha, pág. 2". "Série 341".

O numeral cardinal fica depois do substantivo, quando tem valor de adjetivo: "artigo 212".

b) "Rua Rio de Janeiro, casa número $342 "$.

“Av. São João, casa 235".

"Rua Carangola, número 101".

"Rua Maranhão, 71".

Nos endereços, o numeral cardinal, modificativo da palavra "casa", vem depois, estando ou não omitidas as palavras "número" e "casa" ou uma delas.

c) "Caixa Postal 1031". "5" andar, sala 357".

Nas numerações em geral, como número de ordem, o numeral cardinal vem depois.

2) “... entre a segunda e a terceira dose" (M. Lobato, cit., 169) .

E geralmente variável a posição do numeral ordinal.

a) “art. 9", cap. 5?". "Vol. 2\%, item 4?".

Nas enumerações, é mais frequiente o numeral ordinal posposto .

b) "pela primeira vez", "quinta hora", terceiro dia". 
Há colocações consagradas pelo próprio uso. Não passa de "pedantismo" a inversão nestes casos: "pela vez primeira", "hora quinta", "dia terceiro".

\section{Conjunção:}

a) "Pedro e Alice chegaram." "Maria saiu e João chegou". As conjuncões coordenativas aditivas ficam entre os termos coordenados.

b) "Trabalha, porém, com empenho." "Trabalha com empenho, porém". "Porém, trabalha com empenho".

As conjunções coordenativas adversativas não têm lugar certo, a não ser "mas", que introduz a oração: "...mas trabalha com empenho."

c) "Ou o Brasil acaba com a saúva ou a saúva acaba com o Brasil".

Quando a conjunção coordenativa alternativa tem dois elementos, cada um fica antes de um dos termos coordenados.

d) "A Seleção vence ou empata hoje".

A conjunção coordenativa alternativa de um elemento fica entre as palavras coordenadas.

e) "Não veio, portanto." "Portanto, não veio."

A conjunção coordenativa conclusiva "portanto" não tem lugar fixo.

f) "Penso, logo existo".

A conjunção conclusiva "logo" vem no começo da oração.

g) "Ganhei muito dinheiro, ou seja, dois milhões".

"Cheguei cedo, isto é, às 10 horas."

"João foi brilhante, isto é, ganhou o prêmio."

A conjunção coordenativa explicativa de sentido "corretivo" fica entre os termos coordenados.

h) "Você não me ilude, porque o conheço."

"Vou levá-la comigo, pois preciso de Você."

"Tenha calma, que eu o ajudo." 
A conjunção coordenativa explicativa de sentido "justificativo" vem no começo da oração.

i) "Sei que Você vem."

A conjunção subordinativa integrante introduz a oração subordinada.

j) “Trabalhei sempre, para que seja feliz".

"Faço tudo conforme posso".

"Os pássaros voam como os aviões".

"As esperanças ficam, como permanecem os ideais."

"Vai progredindo à proporção que estuda."

"Porém já cinco sóis eram passados, que dali nos partiríamos..."

"Caso possa, verei você amanhã."

"Fez muito esforço, conquanto tenha perdido."

"Não vou com Você, porque não posso mais."

"Ele correu tanto, que cansou."

A conjunção subordinativa introduz o termo subordinado; vem antes.

Advérbio:

a) "Como vai você?

"Quando virá aqui?"

"Onde está ele?"

Nas interrogações diretas, normalmente o advérbio interrogativo fica no começo da frase. Pode haver inversões enfáticas: "você virá quando?" "Maria foi aonde?"

b) "Quero saber quando o time joga".

"Pergunto como proceder".

Nas interrogações indiretas, o advérbio interrogativo vem no princípio da oração subordinada.

Verbo:

"Acabou-se a guerra." "Venceu o Atlético."

"Cai a resistência." "Cedeu o terreno."

"Ruiu o edifício." "Cresceu o movimento." 
E frequiente a colocação do verbo no começo da frase, com verbos intransitivos, em frases curtas.

Vozes verbais:

a) "A Polícia cercou o prédio."

Coloca-se no começo da frase o sujeito, na voz ativa, para dar relevo ao agente.

b) "O prédio foi cercado pela Polícia."

Coloca-se no começo da frase o sujeito, na voz passiva analítica, para dar relevo ao paciente.

c) "Cercou-se o prédio."

Coloca-se no começo da frase o verbo, na voz passiva sintética, para dar relevo ao processo.

Os extremos da frase:

"Arma virumque cano" [eu canto as armas (= exércitos) e os varões]

O primeiro verso da Eneida, do poeta latino Vergílio, exemplifica um processo estilístico em voga ainda na Língua Portuguesa: a colocação de palavras de significado relevante no começo ou no fim da frase (exército, canto). Nas frases portuguesas esse recurso funciona muito bem. Nota-se facilmente nos versos.

a) "Caminheiro que passas pela estrada,

Seguindo pelo rumo do sertão,

Quando vires a cruz abandonada,

Deixa-a em paz dormir na solidão." (Castro Alves)

Sobreleva a importância semântica das palavras "estrada, sertão, abandonada, solidão", postas no fim dos versos.

b) “Alma minha gentil que te partiste

Tão cedo desta vida descontente,

Repousa la no céu eternamente,

E viva eu cá na terra sempre triste." (Camões)

No quarteto do soneto de Camões, ficam palavras de grande valor no princípio e no fim dos versos: "alma minha, tão cedo, repousa, e viva"; "partiste, descontente, eternamente, triste". 


\section{c) "LÄGRIMAS OCULTAS}

"Se me ponho a cismar em outras eras Em que ri e cantei, em que era querida; Parece-me que foi noutras esferas, Parece-me que foi numa outra vida...

"E a minha triste boca dolorida, Que dantes tinha o rir das primaveras, Esbate as linhas graves e severas, $\mathrm{E}$ cai num abandono de esquecida!

E fico, pensativa, olhando o vago... Toma a brandura plácida dum lago O meu rosto de monja de marfim...

$\mathrm{E}$ as lágrimas que choro, branca e calma, Ninguém as vê brotar dentro da alma! Ninguém as vê cair dentro de mim!"

(Florbela Espanca)

Concentra-se no fim dos versos a força expressiva do poema. Tanto que, combinando-se o final de todos os versos, compõe-se um poemeto que expressa uma simbologia de devaneio:

"em outras eras

era querida

noutras esferas, numa outra vida. . .

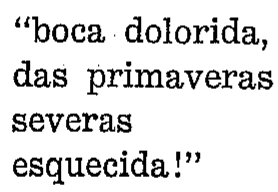


"olhando o vago...

dum lago

de marfim..."

"branca e calma,

dentro da alma,

dentro de mim!"

d) "outras vezes acontece aos protegidos decaírem da graça divina." (M. Lobato, Cidades Mortas, 99)

Há casos, como nessa frase acima, em que a exatidão da escolha e a concisão dispensam outros cuidados: qualquer ordem serve. Mesmo assim, a primeira e a última expressão têm significação forte: outras vezes / a graça divina.

Mesmo em frases concisas, exatas, nota-se o processo da colocação, a concentração no princípio e no fim:

"Inácio era o rei dos acanhados." (Id., ib.)

Inácio / acanhado

"Pelas coisas mínimas avermelhava, saía fora de si e permanecia largo tempo idiotizado." (id., ib.)

Pelas coisas mínimas / idiotizado

"Sizenando deixou o gabinete do ministro profundamente meditativo." (id., 138)

Sizenando / meditativo

e) A título ilustrativo, vejamos o processo em Espanhol, nestes versos de Juana de Ibarbourou:

"Amor que de los cielos dio fuga a las centellas, Para que yo formara mi rebaño de estrellas, Las piedras de la senda con sus manos alisa $\mathrm{Y}$ pone mis labios la flauta de la risa."

(La Pastora, in Las lenguas de diamante, Losada, B. Aires, segunda edición, 34) 
No primeiro verso, brota do princípio e do fim da frase, a imagem do "amor em centelhas". No quarteto, notam-se as palavras expressivas, no fim: "centellas, estrellas, alisa, la risa".

Séries gradativas:

A Língua Portuguesa não tem ordem rígida. Por isso mesmo, a colocação das palavras portuguesas é recurso estilístico importante. E pode revelar arte e exigir técnica. E por exemplo o caso de certas séries gradativas.

Vejamos a explicação do professor português M. Rodrigues Lapa (Estilística da Língua Portuguesa, 28, ss): "O companheiro tornou-se enfadonho, aborrecido, odioso". Os adjetivos (enfadonho, aborrecido, odioso) formam uma série que obedece à lógica dos sentimentos: "primeiro, uma vaga antipatia (enfadonho), depois, um pronunciado desafeto (aborrecido), por fim, um ódio declarado (odioso)."

Curiosa intenção estilística também se vê neste exemplo transcrito de Ferreira de Castro: "A vida só existia através do seu desespero, do silêncio e dos remorsos; dos remorsos, do silêncio e do desespero". A primeira série (desespero, silêncio, remorsos) leva o pensamento até a metade do caminho. Depois, volta o escritor para o ponto de partida, fechando o círculo de trás para frente (remorsos, silêncio, desespero).

Por este mesmo processo, observa R. Lapa, a linguagem popular criou um ditado chistoso: "ao almoço me dão peras, ao jantar peras me dão; à merenda pão com peras, à ceia peras com pão."

Uma série de palavras deve formar um sentido gradativo ascendente (mais comum) ou descendente. Não pode formar-se em qualquer ordem. Não respeitou o preceito o nosso Gonzaga, nas Cartas Chilenas, volta R. Lapa: "Resistem, gritam, ferem, matam, prendem." A graduação ascendente pedia que fosse: "resistem, gritam, prendem, ferem, matam". Justifica R. Lapa (muito entusiasta do poeta inconfidente!) que a intenção era entrelaçar os dois últimos termos, com sentido exclusivo: "matam ou prendem". Mas, no duro mesmo, escorregou o Ouvidor de Vila Rica... 
Se se disser, por exemplo, que o time está mascarado, confiante, eufórico, a série de qualificativos está em desordem. Não forma série gradativa, nem descendente nem ascendente. Logicamente; a confiança dá margem à euforia e esta pode muito bem gerar a máscara, (confiança exagerada). Então, deveria ser assim: o time está confiante, eufórico, mascarado. Aí, está lógico...

Outro aspecto curioso é que, dentro da expressão, pode haver mais de uma série, com os termos entrelaçados: uma série artisticamente misturada com outra. Está ainda em R. Lapa esta frase de Frei Luís de Sousa: "Não havia em todo aquele grande povo senão medo, "desordem", terror, "confusão".

Há aí duas séries:

a) medo - terror;

b) desordem - confusão.

A palavra terror intensifica o significado de medo; a palavra confusão intensifica o significado de desordem. Vemos, assim, que nenhuma destas palavras pode mudar de lugar. No texto de Frei Luís de Sousa, a palavra medo, que inicia as séries entrelaçadas, puxa o fio da significação maior, isto é, a série começada por ela (medo - terror) é mais expressiva.

Nos meus estudos sobre Monteiro Lobato, componho uma frase assim: "um escritor curioso, "diferente", surpreendente, irregular", atraente, "contraditório", fascinante, "impenetrável". Estão entrelaçadas duas séries gradativas ascendentes:

a) curioso - surpreendente - atraente - fascinante;

b) diferente - irregular - contraditório - impenetrável.

Antônio Vieira vai mostrando que os "pecados de consequiência" são aqueles que se cometem sem saber onde vão refletir. Um prejuízo aparentemente simples irá atingir os tetranetos do prejudicado. E já nessa hora o causador do prejuízo estará pagando ao diabo aquilo que ficou devendo a Deus... E faz o pregador esta observação severa: 
"Ficarem os mesmos beneméritos sem o prêmio devido a seus serviços: ficarem seus filhos e netos sem remédio e sem honra, depois de seus pais e avós lhe terem ganhado com o sangue, porque vós the tirastes: ficar a república mal servida: os bons escandalizados: os príncipes murmurados: o governo odiado: o mesmo conselho em que assitis, ou presidis, infamado: o merecimento sem esperança: o prêmio sem justiça: o descontentamento com desculpa: Deus ofendido, o rei enganado, a pátria destruída." $(\mathrm{I}, 60)$

O texto apresenta 13 elementos binários:

1) benemérito/prêmio;

2) filhos/honra;

3) república/servida;

4) bons/escandalizados;

5) príncipes/murmurados;

6) governos/odiados;

7) conselho/infamado;

8) merecimento/esperança;

9) prêmio/justiça;

10) descontentamento/desculpa;

11) Deus/ofendido;

12) rei/enganado;

13) pátria/destruída.

Seguindo os conceitos lógicos, esses elementos se agrupam por três idéias básicas:

a) sentimento cívico;

b) maldade;

c) bondade.

Separados assim logicamente, formam três séries de conceitos:

- nobreza (principes) - república - pátria: sentimento civico;

- escândalo - traição (rei enganado) - infâmia - descontentamento - desespero - ódio: maldade; 
- benemerência - honra - justiça - Deus: bondade.

Respeitado esse esquema, a colocação no texto ficaria assim:

"Ficarem os bons escandalizados: o rei, enganado: o mesmo conselho, infamado: o descontentamento, com desculpa: o merecimento, sem esperança: o governo, odiado: os príncipes, murmurados: ficar a república, mal servida: a pátria, destruída: os mesmos beneméritos, sem o prêmio devido a seus serviços: os filhos e netos, sem remédio e sem honra: o prêmio, sem justiça: Deus, ofendido."

Por um critério semântico, poder-se-á localizar em cada elemento uma palavra de significação relevante e formar a série ascendente, da menos para a mais significativa. As palavras que formam a série são: descontentamento - prêmio - escandalizado infamado - odiados - república - príncipes - rei - honra - esperança - pátria - justiça - Deus. Com esse critério, o texto fica assim:

"Ficar o descontentamento com desculpa: ficarem os mesmos beneméritos sem o prêmio devido a seus serviços: os bons escandalizados: o mesmo conselho, infamado: o governo, odiado: a república, mal servida: os príncipes, murmurados: o rei, enganado: ficarem os filhos e netos sem remédio e sem honra: o merecimento, sem esperança: a pátria, destruída: o prêmio, sem justiça: Deus, ofendido."

Se o texto de Vieira está ainda superior, é porque o gênio superou a técnica. Enfim, escrever bem é igual rapadura: é doce, mas não é mole, não... Sente-se, por tudo isso, a extensão do verso de Olavo Bilac:

"Trabalha, e teima, e lima, e sofre, e sua!"

(A um poeta) 
Importância do Ritmo

"R I T MO"

Cecília Meireles

"O RITMO em que gemo

doçuras e mágoas

é um dourado remo

por dourados águas.

Tudo, quando passo,

olha-me e suspira.

- Será meu compasso

que tanto os admira?"

(Obra Poética, Rio, Aguilar, 1958, 139)

O ritmo - qualidade primordial do estilo - é a musicalidade da frase. Marca-lhe o andamento feliz: faz as palavras correr suavemente,

"como quem semeia, e não como quem ladrilha ou azuleja",

"tão naturais que vão caindo, tão próprias que venham

nascendo" (Vieira, I, 16, 17, Sermões, Lelo).

Sem tropeço. Com boa colocação, bom gosto, habilidade, vocabulário bem escolhido e adequado, compõe-se a frase bem ritmada, com equilíbrio entre seus elementos. Sem ritmo a frase cambaleia, pende para um lado só, sai aos arrancos.

A frase ritmada acompanha a cadência do verso, encontram-se nela versos inteiros: "Verdes mares bravios de minha terra natal, onde canta a jandaia nas frondes da carnaúba." (Alencar)

ver/des $/ \mathrm{ma} / \mathrm{res} / \mathrm{bra} / \mathrm{vi} / \mathrm{os}$

$\begin{array}{llllll}1 & 2 & 3 & 4 & 5 & 6\end{array}$

$\mathrm{de} / \mathrm{mi} / \mathrm{nha} / \mathrm{te} / \mathrm{rra} / \mathrm{na} / \mathrm{tal}$

$\begin{array}{lllllll}1 & 2 & 3 & 4 & 5 & 6 & 7\end{array}$

on/de /can/ta a /jan/da/ia

$\begin{array}{llllll}1 & 2 & 3 & 4 & 5 & 6\end{array}$

nas /fron/des /da /car/na/ú/ba

$\begin{array}{lllllll}1 & 2 & 3 & 4 & 5 & 6 & 7\end{array}$ 
No texto de Iracema, notam-se 2 metros de 6 sílabas e 2 de 7 sílabas (redondilha maior), alternadamente.

"Este Rio de Janeiro de hoje é tão outro do que era, que parece antes, salvo o número de pessoas, uma cidade de exposição universal." (Machado de Assis)

No trecho da carta de Machado de Assis, escrito com a presteza e espontaneidade da correspondência (Aguilar, III, 1040), o ritmo é tão bom que se formam conjuntos métricos de estruturas iguais, quase sem discrepância:

$\mathrm{Es} /$ te $/ \mathrm{Ri} / \mathrm{o} / \mathrm{de} / \mathrm{Ja} / \mathrm{nei} / \mathrm{ro}$

$\begin{array}{lllllll}1 & 2 & 3 & 4 & 5 & 6 & 7\end{array}$

de ho/je é /tão /ou/tro /do /que e/ra

$\begin{array}{lllllll}1 & 2 & 3 & 4 & 5 & 6 & 7\end{array}$

que/ $\mathrm{pa} / \mathrm{re} / \mathrm{ce}$ an/tes

$\begin{array}{llll}1 & 2 & 3 & 4\end{array}$

$\mathrm{sal} /$ vo o /nú/me/ro

$1 \quad 2 \quad 3$

$\mathrm{de} / \mathrm{pe} / \mathrm{sso} / \mathrm{as}$

$1 \quad 2 \quad 3$

$\mathrm{u} / \mathrm{ma} / \mathrm{ci} / \mathrm{da} / \mathrm{de}$

$\begin{array}{llll}1 & 2 & 3 & 4\end{array}$

de $\mathrm{ex} / \mathrm{po} / \mathrm{si} /$ ção

$\begin{array}{llll}1 & 2 & 3 & 4\end{array}$

$\mathrm{u} / \mathrm{ni} / \mathrm{ver} / \mathrm{sal}$

$\begin{array}{llll}1 & 2 & 3 & 4\end{array}$

Notam-se 2 metros de 7 sílabas, 5 de 4 sílabas, e 2 de 3 sílabas.

Como na poesia, a acentuação com espaços certos - distribuída naturalmente na prosa - marca o compasso da frase. Nesse ponto, a leitura dos poetas ajuda muito, e decisivamente.

$\mathrm{Na}$ poesia, é claro, o ritmo é fundamental. E por exemplo o forte de Gonçalves Dias. O ritmo impecável da "Canção do Exílio" permite cantar o texto com um número ilimitado de melodias: 
"Minha terra tem palmeiras

Onde canta o sabiá.

As aves que aqui gorjeiam

Não gorjeiam como lá."

Por brincadeira, cante-se o texto como se fosse: A Casinha Pequenina, A Perpétua, Cirandinha, Bigorilho, A Fonte do Tororó...

O ritmo marcial do "Y Juca Pirama" assinala o compasso dos tambores de índios:

"No meio das tabas de amenos verdores,

Coberto de troncos, cercados de flores,

Alteia-se o teto da altiva Nação.

São muitos seus filhos nos ânimos fortes,

Temíveis na guerra que, em densas coortes,

Assombram das matas a imensa extensão."

A frase cadenciada facilita a elocução e ganha em expressividade. A palavra no lugar certo valoriza o estilo, de acordo com o ritmo da frase. O cancioneiro popular é um excelente repertório de frases bem ritmadas, que mostram o bom lugar das palavras. Com ritmo impecável, Ataúlfo Alves diz sua frase

"na cadência bonita do samba"!

A sonoridade da própria palavra "cadência" coincide com a cadência da frase. No seguinte trecho de Chico Buarque

"a felicidade era tão vizinha

que, de tolo, até pensei

que fosse minha",

veja-se a espontaneidade rítmica da expressão "de tolo".

Observe-se, ou sinta-se, o ritmo destes versos (4 redondilhas e um alexandrino) de Noel Rosa (Hotel de Estrelas) :

"O orvalho vem caindo, vem molhar o meu chapéu,

e também já vão sumindo

as estrelas lá no céu!

Tenho passado tão mal:

a minha cama é uma folha de jornal!" 
O ritmo é assim esse elemento fundamental de expressividade. Torna a frase fácil, agradável, suave, melódica, comunicativa. Tanto valoriza a frase, que até lhe esconde os defeitos.

A linda letra simples da canção "Amélia", da competência literária de Mário Lago, modificada nalgum ponto (neste, talvez?) pelo talento musical de Ataúlfo Alves, é um desses casos. No verso - "não vê que eu sou um pobre rapaz?" - a colocação do adjetivo está contra os costumes da Língua. O texto vem dizendo que o rapaz é "pobre" (sem recursos), e a mulher é gastadora "Você só pensa em luxo e riqueza / tudo o que Você vê Você quer / Você não sabe o que é consciência / não vê que eu sou um pobre rapaz?"

$\mathrm{E}$ aí então vem a lembrança de Amélia: "Amélia não tinha a menor vaidade / Amélia é que era mulher de verdade."

De modo que, naquele verso, deveria ser "rapaz pobre" (sem recursos) e não "pobre rapaz" (infeliz). Deu-se porém que a boa melodia do verso, a cadência, o ritmo afinal - encobriu a falha: ninguém percebe a má colocação.

Porém, todavia, contudo. As gramáticas costumam dizer que essas partículas vêm entre vírgulas, e são pospositivas. Assim, seria: "comunico, porém, a meus amigos". Mas, não é de rigor. Pode-se muito bem dizer, com vírgula ou seu vírgula: "comunico a meus amigos porém" e "porém comunico a meus amigos". Depende só do ritmo. No exemplo, a melhor colocação é mesmo a primeira. Favorece o ritmo. Tanto que dá a medida de um verso decassílabo heróico: com acentuação na $6^{\mathrm{a}}$ e na $10^{n}$ sílabas. Mas nada tem que ver com a partícula adversativa. Ela não tem lugar certo na frase. Se não fosse assim, como é que ia ser o verso de Luís de Camões?

"Porém já cinco sóis eram passados".

A palavra "porém" começa a frase e não há pausa depois dela. O compasso do verso é forte, e a frase, cadenciada. Tão expressivo é o ritmo que, na fluência do verso, o verbo "eram" torna-se oxítono, como se fosse "erão". O ritmo força a expressão do verso como um jâmbico (acentuação tônica nas sílabas pares): 
$\mathrm{Po} / \mathrm{rém} / \mathrm{já} / \mathrm{cin} / \mathrm{co} /$ sói/z e/rão /pa/ssa/dos

$\begin{array}{llllllllll}1 & 2 & 3 & 4 & 5 & 6 & 7 & 8 & 9 & 10\end{array}$

Mas bem poderia Camões ter preferido a colocação da partícula adversativa depois do verbo auxiliar:

“Já cinco sóis eram porém passados".

Sem alterar a tonicidade da última sílaba de "eram", o verso fica decassílabo sáfico, com acentuação na $4^{\text {a }}$ (sóis) e na $8^{a}$ (rém). Mas o Poeta preferiu começar com a adversativa, mantendo o decassílabo "heróico" ( $6^{n}$ e 10") que é do seu gosto. Portanto, o lugar da adversativa depende do ritmo, como nesta frase de Monteiro Lobato (O Espião Alemão) :

"A munição porém encareceu".

A frase corresponde à medida de um decassílabo heróico acentuação na $6^{n}$ (rém) e na $10^{n}$ (ceu). Mas, se a partícula fosse para o fim da frase, não haveria prejuízo para o ritmo:

A munição encareceu porém.

Agora a medida é a de um verso sáfico: $4^{n}$ (ção), $8^{a}$ (ceu) e $10^{\mathrm{a}}$ (rém).

E também com a partícula no princípio:

Porém a munição encareceu.

Volta à medida do decassílabo heróico: $6^{a}$ (ção) e 10 (ceu).

Enfim, o ritmo - como as tonalidades emotivas, a ênfase, a simetria, a eufonia (harmonia) - pertence ao domínio da expressividade (Ullmann, Lenguaje y Estilo, Aguilar, Madrid, 1968, 122).

O ritmo torna a frase correntia, fluente, melódica. Fala-se, por isso, num ritmo "mais suave e mais equilibrado" (Ullmann, cit., 124) .

Os pronomes átonos oblíquos. Na linguagem de Portugal, pode dizer-se que o pronome tem lugar certo, não há hesitação: o lugar normal do pronome é depois do verbo. Daí só sairá por razão especial. Esse motivo é o ritmo. 
Diz-se, por exemplo, que se prefere a próclise:

a) nas frases negativas: não me interessa esse assunto. A pronúncia da negativa "não" pede o pronome antes do verbo, para favorecer o ritmo;

b) com partículas subordinativas: quando me vê, corre, também por causa do ritmo;

c) com pronomes indefinidos, sempre pela mesma razão: ninguém me quer.

Nas frases optativas, depende do elemento que começa a frase. O pronome ficará proclítico, se se começa pelo sujeito - Deus te guie. E ficará enclítico, se o sujeito é proposto - livre-nos Deus. A deslocação da primeira frase - Deus te guie - socorre ao ritmo da frase.

O mesmo ocorre em frases exclamativas - Deus me livre!; livre-me Deus!

Já a preferência da língua oral do Brasil pela próclise - não tem que ver com o ritmo. Dizemos - Maria me ("mi") disse coisas lindas. Em Portugal, diz-se - Maria disse-me (m') coisas lindas. A completa atonicidade do pronome "português" não the dá lugar senão depois do verbo, amparado na sílaba tônica do verbo. A semi-tonicidade do pronome "brasileiro" permite-lhe a deslocação. Antes do verbo, acentua-se a relativa autonomia fonética do pronome, porque ele se destaca do verbo, e se pronuncia com valor fonético próprio. Não tem o Brasil pronome inteiramente átono. $\overline{\mathrm{E}}$ tônico e menos tônico. Daí chegarmos ao ponto de começar a frase com o pronome - Me dá um dinheiro aí! - em que o pronome me ("mi") soa tônico.

Em resumo, as normas tradicionais (portuguesas) de colocação do pronome átono foram ditadas pelo ritmo, que é, também neste caso, elemento de expressividade e melódico da frase. Mas a preferência brasileira pela próclise é um problema fonético e não de ritmo. 
Observações sobre a colocação do pronome, para comodidade didática:

1. O pronome átono português é por natureza enclítico: o lugar normal é depois do verbo - ênclise.

2. "... mas ninguém os vê." (CDA.)

"Do sangue do meu coração

"Que te despreza e te compreende" (V. Morais).

"Por que vos deixais imóveis" (id.).

"Não te vira no bojo secular" (id.).

"Você quer que tho carreguem de oiro!" (M. Torga).

"... se queres que te fale com toda a franqueza," (id.)

"Nem the permitiam queixas." (G. Ramos)

"Este desventurado estilo que hoje se usa, os que o querem honrar..." (Vieira).

Por motivo de ordem rítmica, pode o pronome deslocar-se para antes do verbo, dando-se a próclise, mais comum na língua oral; a ênclise, na língua literária. Na verdade, o pronome continua "enclítico"; só que a sílaba anterior, que the serve de apoio, não é a do verbo - cf. Said Ali, Dificuldades. Pode dar-se a próclise:

a) "Não me importa"; por causa de uma palavra negativa;

b) "Quando te encontrei, pensei que te queria; "por causa de uma conjunção subordinativa;

c) "O homem que se enganou"; por causa de um pronome relativo;

d) "Muitos o querem senador"; por causa de um pronome indefinido;

e) "Deus o guarde"; nas frases optativas;

f) "Por isso nos púlpitos se trabalha tanto, e se navega tão pouco." Unicamente por causa do ritmo (1. exemplo) e devido a uma conjunção coordenativa, também para servir ao ritmo;

g) "O jogador se poupou"; no uso jornalístico atual, por causa do sujeito. 
Observação: "Ninguém me ama" e "ninguém, agora, ama-me tanto", ocorrendo uma pausa após a palavra que provocaria a próclise, deixa de haver o motivo para deslocação do pronome. Em todo caso, o que manda é o ritmo.

3. "Bamba, moída de trabalhos, deitar-se-ia em pregos." (G. Ramos)

"Dar-te-ei todo esse poder" (v. Morais).

Pode dar-se a mesóclise, com o futuro do pretérito e com o futuro do presente, se não houver motivo para próclise. Nestes casos nunca ocorre a ênclise.

4. "Riram-se-lhe na cara." (M. Torga). "Subitamente, abriu-se-lhe sobre o dorso um alçapão" (id.)

$\mathrm{Na}$ língua literária, costuma ocorrer a ênclise de dois pronomes.

5. "Não adianta querer a nota, porque não ta darei". "Pediu uma audiência e a autoridade ma concedeu". "Não tho dei".

$\mathrm{Na}$ língua literária, pode ocorrer a contração de dois pronomes: te $+\mathrm{a}=\mathrm{ta} ; \mathrm{me}+\mathrm{a}=\mathrm{ma} ; \mathrm{lhe}+\mathrm{o}=$ lho.

\section{Locuções Verbais}

1. "Pode-se dizer assim"; "ia-se virando como podia". "Pode dizer-se assim"; "ia virando-se como podia".

Segundo a tradição gramatical, o pronome é ligado por hífen, encliticamente, a um dos dois verbos da locução. Mas, nunca se punha solto entre os dois verbos da locução.

2. "Não se pode dizer assim." Havendo razão, pode haver próclise, com a locução.

3. "Quero te falar hoje." "Pode se dizer isso mesmo."

A língua oral do Brasil consagrou a pronúncia do pronome solto entre os verbos da locução. A língua literária contemporânea já fixou o mesmo uso. Assim, a colocação é perfeitamente corrente. 
4. "Me dá um dinheiro aí!"

Segundo a tradição gramatical, não se pode começar a frase com o pronome átono oblíquo. A língua oral do Brasil já consagrou esse emprego. Mas, a língua literária contemporânea ainda hesita em fixar o uso. Assim, a língua escrita em geral deve ainda evitar essa colocação do pronome.

5. "Era como se as mãos e os braços da multidão fossem agarrá-lo, subjugá-lo, espremê-lo num canto de parede."

A forma pronominal "lo" explica-se assim:

a) a forma antiga do pronome era "lo";

b) o fonema "lê" / $/$ assimilou o "r", isto é, "r" passou a " $\mathrm{l}$ ";

c) a simplificação ortográfica eliminou um dos "eles" (o primeiro)

Tal acontece, por exemplo, nestas formas verbais:

- Fizeste-lo, compraste-lo (segunda do plural);

- Compramo-lo, condenamo-lo (primeira do plural).

6. "Tinham-na por orientadora."

Neste caso, o fonema nasal anterior (m) nasalou o fonema seguinte.

7. "Pois te não move a culpa que não tinha" (Camões) .

A língua clássica costuma colocar o pronome em próclise, no meio de duas palavras que lhe provocam a deslocação. Esse uso ainda corresponde à fala de Portugal. Mas não representa a linguagem do Brasil. 


\section{RESUMO DA QUESTÃO POR COMODIDADE DIDÁTICA}

1. O pronome átono português é normalmente enclítico.

2. A colocação do pronome átono depende essencialmente do ritmo.

3. A língua literária prefere a ênclise.

4. A língua oral do Brasil prefere a próclise.

5. O pronome no meio de duas palavras deslocadoras, em próclise, não corresponde ao uso do Brasil.

6. Não se dá ênclise com os futuros nem com o particípio passado.

7. A língua do Brasil consagrou a colocação do pronome no meio dos verbos, solto, nas locuções; a língua literária fixou o uso.

8. Não se começa a frase, na língua escrita, com o pronome átono.

9. A língua do Brasil consagrou a colocação do pronome no início da frase, mas a língua literária contemporânea hesita em fixar o uso.

\section{REFERÊNCIA BIBLIOGRÄFICA}

ALI, M. Said. Dificuldades de língua portuguesa. Rio de Janeiro, Acadêmica, 1966.

BRANDAO, Cláudio. Sintaxe clássica portuguesa. Belo Horizonte, Imprensa da Universidade de Minas Gerais, 1963.

CASTAGNINO, Raúl. Análise literária. São Paulo, Editora Mestre Jou, 1968.

DIAS, Augusto Epiphanio da Silva. Sintaxe histórica portuguesa. $4^{a}$ ed. Lisboa, Livraria Clássica Editora, 1959.

LAPA, M. Rodrigues. Estilística da lingua portuguesa. Rio de Janeiro, Acadêmica, 1968 .

SILVEIRA, Sousa de. Lições de português. Rio de Janeiro, Livros de Portugal, 1964. 